\title{
PENGARUH GOOD CORPORATE GOVERNANCE TERHADAP NILAI PERUSAHAAN DENGAN PROFITABILITAS SEBAGAI VARIABEL INTERVENING (Studi Pada Perusahaan Perbankan Di Bursa Efek Indonesia)
}

\author{
G. A. Sri Oktaryani ${ }^{1}$, I Nyoman Nugraha A. P. ${ }^{2}$, Siti Sofiyah ${ }^{3}$, \\ Iwan Kusuma Negara ${ }^{4}$, I Gede Mandra ${ }^{5}$ \\ ${ }^{1}$ Fakultas Ekonomi dan Bisnis Universitas Mataram,oktaryani@gmail.com \\ ${ }^{2}$ Fakultas Ekonomi dan Bisnis Universitas Mataram, ibobid@yahoo.com \\ ${ }^{3}$ Fakultas Ekonomi dan Bisnis Universitas Mataram,sofiyah_siti@ymail.com \\ ${ }^{4}$ Fakultas Ekonomi dan Bisnis Universitas Mataram, iwanegara@tahoo.com \\ ${ }^{5}$ Fakultas Ekonomi dan Bisnis Universitas Mataram, mandragede@yahoo.co.id
}

\begin{abstract}
This research examines the effect of Good Corporate Governance (GCG) on firm value by using profitability as intervening variable. Profitability is proxied by Return on Asset (ROA) and Return on Equity (ROE). This study used a quantitative approach and path analysis. The population consists of 35 firms that were listed in Banking sector of Indonesian Stock Exchange over period 2013 - 2015. There are 34 firms are choosen as samples which has published GCG composit index throughout observation years and has not done corporate action that could affect the stock price directly. The findings show that GCG has positive and significant direct effect on firm value. Furthermore, ROA has positive impact on firm value; meanwhile ROE has negative impact on firm value. The results also show that the better the implementation of GCG the higher the Return on Asset. Moreover, the indirect effect of GCG on firm value through profitability is not significant.

Keywords: GCG, profitability, ROA, ROE, firm value.
\end{abstract}

\begin{abstract}
ABSTRAK
Penelitian ini menguji pengaruh Good Corporate Governance (GCG)terhadap nilai perusahaan dengan profitabilitas sebagai variabel intervening. Profitabilitas diproksikan menggunakan Return on Asset (ROA) dan Return on Equity (ROE). Penelitian ini adalah penelitian dengan pendekatan kuantitatif dengan analisis jalur. Populasi meliputi 35 perusahaan yang terdaftar di Bursa Efek Indonesia selama periode 2013-2015. Terpilih sebanyak 34 menjadi sampel penelitian yang mempublikasi GCG composite index selama tahun pengamatan dan kegiatan perusahaan belum berdampak pada harga saham secara langsung. Temuan penelitian menunjukan GCG berpengaruh positif pada nilai perusahaan sementara ROE berdampak negatif pada nilai perusahaan. Hasil juga menunjukan penerapan GCG yang semakin baik meningkatkan ROA. Selain itu, tidak terdapat pengaruh tidak langsung GCG terhadap nilai perusahaan.

Kata Kunci: GCG, profitabilitas, ROA, ROE, nilai perusahan.
\end{abstract}

\section{PENDAHULUAN}

Struktur organisasi yang memisahkan antara pemilik dan manajemen dapat menimbulkan konflik kepentingan di dalam organisasi tersebut. Pemegang saham selaku pemilik perusahaan ingin agar manajemen bekerja demi kepentingan pemegang 
saham, namun manajer bisa saja bertindak sebaliknya. Menurut teori keagenan, salah satu cara untuk mengatasi ketidaksamaan atau ketidakselarasan kepentingan antara manajer dengan pemegang saham serta antara manajer dengan kreditur adalah dengan pengelolaan perusahaan yang baik. Corporate Governance merupakan suatu mekanisme yang digunakan untuk memastikan bahwa para penyedia dana yang terdiri dari pemegang saham dan bondholders dari suatu perusahaan memperoleh pengembalian dari kegiatan yang dijalankan oleh manajer (Kemalasari, 2009).

Bank sebagai lembaga intermediasi memiliki peran penting dalam perekonomian karena lembaga ini menghimpun dana dari masyarakat dan selanjutnya menyalurkannya kembali dalam bentuk kredit. Krisis ekonomi melanda Indonesia pada tahun 1997 yang menyebabkan terguncangnya sektor perbankan, krisis keuangan global yang terjadi di tahun 2008 serta kasus lainnya membelit perusahaan perbankan mendorong perlu ditingkatkannya penerapan Good Corporate Governance (GCG) agar bank lebih tahan dalam menghadapi krisis.Menurut Budiartini, Rudy dan Purwanti (2012), salah satu penyebab rentannya perusahaan-perusahaan di Indonesia terhadap gejolak perekonomian adalah lemahnya penerapan GCG.

Mekanisme pengawasan bank merujuk pada prinsip-prinsip Good Corporate Governance (GCG) yang diatur dalam Peraturan Bank Indonesia nomor 8/14/PBI/2006. Prinsip-prinsip GCG yang diatur terdiri dari transparansi (transparency), akuntabilitas (accountability), pertanggungjawaban (responsibility), independensi (independency) dan kewajaran (fairness).

Corporate Governance merupakan konsep yang diajukan guna peningkatan kinerja perusahaan melalui supervisi atau monitoring kinerja manajemen serta menjamin akuntabilitas manajemen terhadap stakeholder dengan mendasarkan pada kerangka peraturan (Nasution dan Setiawan dalam Tjondro dan Wilopo, 2011). Berdasarkan Surat Edaran Bank Indonesia nomor 15/15/DPNP yang diterbitkan tanggal 29 April 2013, disebutkan bahwa dalam pelaksanaan GCG diperlukan keberadaan Komisaris Independen dan Pihak Independen untuk menghindari benturan kepentingan dalam pelaksanaan tugas di seluruh tingkatan atau jenjang organisasi Bank. Dengan demikian penerapan GCG dapat mendorong manajemen perusahaan agar lebih transparan dan berhati-hati dalam pengelolaan bank karena adanya pengawasan dari pihak-pihak yang Independen, sehingga pihak manajemen dapat lebih efisien dalam melakukan tugasnya untuk meningkatkan laba perusahaan dan memaksimalkan nilai perusahaan.

Pengaruh penerapan corporate governance terhadap nilai perusahaan telah ditemukan oleh sejumlah peneliti. Berdasarkan hasil penelitian tersebut, terungkap bahwa corporate governance berpengaruh positif terhadap nilai perusahaan (Bauer, Guenster dan Otten,2004; Retno dan Priantinah, 2012; Hendrayana dan Yasa, 2015).

Kemampuan perusahaan menghasilkan laba juga berpengaruh terhadap nilai perusahaan. Semakin tinggi profitabilitas maka semakin tinggi pula nilai perusahaan (Chen dan Chen, 2011; Hendrayana dan Yasa, 2015). Namun hasil penelitian Fahrizal (2013) membuktikan hal yang sebaliknya, yaitu bahwa profitabilitas berpengaruh negatif terhadap nilai perusahaan.

Forum for Corporate Governance in Indonesia (FCGI) mengungkapkan bahwa selain dapat memberikan proteksi bagi pemegang saham dan pemilik dana lainnya, penerapan GCG juga dapat meningkatkan kinerja bisnis dan harga saham. Kinerja bisnis bisa diukur melalui kemampuan perusahaan dalam menghasilkan laba. Pengaruh GCG terhadap profitabilitas dibuktikan melalui hasil penelitian yang dilakukan oleh Joh 
(2003) menemukan bahwa terdapat hubungan searah antara GCG dan profitabilitas, dimana penerapan GCG yang kurang baik berpengaruh terhadap rendahnya profitabilitas perusahaan. Namun, hasil penelitian Bauer, Guenster dan Otten (2004) serta Zamani dan Moeljadi (2012) mengungkapkan bahwa corporate governance berpengaruh negatif terhadap profitabilitas.

Berdasarkan teori, hasil penelitian terdahulu dan fenomena yang terjadi di sektor perbankan maka menarik untuk dilakukan penelitian tentang pengaruh Good Corporate Governance (GCG) terhadap nilai perusahaan dengan profitabilitas sebagai variabel intervening.

\section{STUDI LITERATUR}

\section{Good Corporate Governance (GCG)}

Forum for Corporate Governance in Indonesia (FCGI) mengungkapkan bahwa corporate governance memberikan perlindungan efektif bagi pemegang saham dan kreditor sehingga mereka yakin akan memperoleh pengembalian atas investasinya dengan benar. corporate governance juga membantu menciptakan lingkungan kondusif demi terciptanya pertumbuhan yang efisien dan sustainable di sektor korporasi. Sesuai dengan definisi dari Cadbury Committee, Good Corporate Governance (GCG) didefinisikan sebagai seperangkat peraturan yang mengatur hubungan antara pemegang saham, manajer, pihak kreditur, pemerintah, karyawan serta para pemegang kepentingan intern dan ekstern lainnya yang berkaitan dengan hak-hak dan kewajiban mereka, atau dengan kata lain suatu sistem yang mengatur dan mengendalikan perusahaan (www.fcgi.or.id).

Prinsip-prinsip dasar GCG tertuang dalam Peraturan Bank Indonesia nomor 8/14/PBI/2006 yang dijelaskan secara lebih lanjut oleh Komite Nasional Kebijakan Governance (KNKP, 2012) serta Surat Edaran Bank Indonesia nomor 15/15/ DPNP yang diterbitkan tanggal 29 April 2013. Prinsip-prinsip dasar GCG terdiri dari transparansi (transparency), akuntabilitas (accountability), pertanggungjawaban (responsibility), independensi (independency) dan kewajaran (fairness).

Peraturan Bank Indonesia nomor 13/1/PBI/2011 mengatur tentang kewajiban bank umum untuk melakukan penilaian sendiri (self assessment) tingkat kesehatan bank dengan menggunakan pendekatan risiko (Risk Based Bank Rating) yang antara lain mencakup penilaian faktor Good Corporate Governance (GCG). Self assessment GCG merupakan penilaian terhadap pelaksanaan prinsip-prinsip GCG, yang berisikan sebelas faktor penilaian pelaksanaan GCG : (1) pelaksanaan tugas dan tanggung jawab Dewan Komisaris; (2) pelaksanaan tugas dan tanggung jawab Direksi; (3) kelengkapan dan pelaksanaan tugas Komite; (4) penanganan benturan kepentingan; (5)penerapan fungsi kepatuhan; (6) penerapan fungsi audit intern; (7) penerapan fungsi audit ekstern; (8) penerapan manajemen risiko termasuk sistem pengendalian intern; (9) penyediaan dana kepada pihak terkait (related party) dan penyediaan dana besar (large exposures); (10) transparansi kondisi keuangan dan non keuangan Bank, laporan pelaksanaan GCG dan pelaporan internal serta (11) rencana strategis Bank.

Dalam pelaporan Self assessment GCG satuan pengukurannya adalah nilai absolut yang sudah ditentukan yang disebut dengan nilai komposit. Berikut ini adalah nilai komposit dalam GCG bank: 
a) peringkat komposit 1 mencerminkan Manajemen Bank telah melakukan penerapan GCG yang secara umum "sangat baik";

b) peringkat komposit 2 mencerminkan Manajemen Bank telah melakukan penerapan GCG yang secara umum "baik";

c) peringkat komposit 3 mencerminkan Manajemen Bank telah melakukan penerapan GCG yang secara umum "cukup baik";

d) peringkat komposit 4 mencerminkan Manajemen Bank telah melakukan penerapan GCG yang secara umum "kurang baik";

e) peringkat komposit 5 mencerminkan Manajemen Bank telah melakukan penerapan GCG yang secara umum "tidak baik".

\section{Profitabilitas}

Profitabilitas mengukur kemampuan perusahaan dalam memperoleh laba relatif terhadap penjualan yang dimiliki, total aktiva maupun modal sendiri (Sartono, 2001). Profitabilitas penting dalam usaha mempertahankan kelangsungan hidupnya dalam jangka panjang, karena profitabilitas menunjukkan apakah badan usaha tersebut mempunyai prospek yang baik di masa yang akan datang. Rasio profitabilitas dalam penelitian ini diukur dengan Return on Asset (ROA) dan Return on Equity (ROE). ROA menunjukkan kemampuan perusahaan dalam mengelola seluruh asetnya untuk menghasilkan keuntungan dan rasio ini merupakan salah satu rasio yang menjadi tolok ukur kinerja bank yang ditetapkan oleh Bank Indonesia. Sedangkan ROE merupakan rasio yang menunjukkan kemampuan perusahaan dalam menghasilkan laba bersih untuk pengembalian ekuitas pemegang saham. Semakin tinggi rasio ROA dan ROE maka kinerja perusahaan semakin baik.

\section{Nilai perusahaan}

Nilai perusahaan merupakan persepsi investor terhadap tingkat keberhasilan perusahaan yang terkait erat dengan harga sahamnya (Sujoko dan Soebiantoro (2007) dalam Hermuningsih, 2013). Harga saham yang digunakan umumnya mengacu pada harga penutupan (clossing price), dan merupakan harga yang terjadi pada saat saham diperdagangkan di pasar saham. Nilai perusahaan dapat diukur dengan Price to Book Value (PBV). Dimana rasio PBV yang tinggi akan meningkatkan kepercayaan pasar terhadap prospek perusahaan dan mengindikasikan kemakmuran pemegang saham yang tinggi (Soliha dan Taswan (2002) dalam Hermuningsih, 2013).

\section{Teori Keagenan (Agency Theory)}

Jensen dan Meckling (1976) dalam Atmaja (2008) mengungkapkan bahwa teori keagenan menjelaskan hubungan antara agen (manajer) dan principal (pemegang saham). Hubungan antara agen dan principal biasanya dalam situasi asimetri informasi, dimana agen memiliki lebih banyak informasi dibandingkan principal karena yang menjalankan kegiatan operasional adalah agen (manajer). Di satu sisi, pemegang saham ingin agar manajer bekerja untuk mensejahterakan pemegang saham namun manajer perusahaan bisa saja bertindak sebaliknya. Karena munculnya konflik kepentingan tersebut maka pemegang saham harus mengeluarkan sejumlah biaya yang disebut dengan agency cost untuk melakukan pengawasan secara total terhadap para manajer. 


\section{Efisiensi Pasar Modal}

Pasar modal yang efisien adalah pasar modal dimana harga aktiva financial yang diperjualbelikan mencerminkan seluruh informasi yang ada dan dapat menyesuaikan diri secara tepat terhadap informasi baru. Pasar efisien yang ditinjau dari sudut informasi saja disebut dengan efisiensi pasar secara informasi. Sedangkan pasar yang ditinjau dari sudut kecanggihan pelaku pasar dalam mengambil keputusan berdasar informasi yang tersedia disebut dengan efisiensi pasar secara keputusan. Namun agar pasar modal dapat efisien secara informasi maka pasar modal tersebut harus efisien secara operasi, misalnya kemudahan dalam memperjualbelikan sekuritas. (Atmaja, 2008)

\section{Teori Sinyal}

Pada dasarnya prinsip ini mengajarkan bahwa setiap tindakan mengandung informasi. Teori sinyal adalah suatu tindakan yang diambil pihak manajemen perusahaan untuk memberikan petunjuk atau informasi bagi investor tentang bagaimana manajemen memandang prospek perusahaan (Atmaja, 2008). Dorongan perusahaan untuk memberikan informasi adalah karena terdapat asimetri informasi antara perusahaan dan pihak luar (khususnya investor dan kreditur). Teori ini menyatakan bahwa investor dapat membedakan antara perusahaan yang memiliki nilai tinggi dengan perusahaan yang memiliki nilai rendah. Perusahaan yang selalu menghasilkan profit memberikan sinyal tentang perusahaannya yang relatif tidak mudah mengalami kebangkrutan dan bentuk lain dari financial distress, dibanding perusahaan yang kurang menghasilkan profit.

\section{PENGEMBANGAN HIPOTESIS}

\section{Pengaruh GCG Terhadap Nilai Perusahaan}

Penerapan GCG akan membuat proses pengambilan keputusan berlangsung secara lebih baik sehingga dapat menghasilkan keputusan yang optimal, dapat meningkatkan efisiensi serta terciptanya budaya kerja yang lebih sehat (Maksum (2005) dalam Tjondro dan Wilopo, 2011). Sehingga publikasi hasil penilaian GCG akan memberikan sinyal bahwa pengelolaan perusahaan dilakukan secara baik. Hal ini didukung oleh Berbagai penelitian telah membuktikan secara empiris penerapan GCG terhadap Nilai Perusahaan. Diantaranya adalah penelitian Bauer, Guenster dan Otten (2004), Retno dan Priantinah (2012), Hendrayana dan Yasa (2015) serta Tempone (2016) yang membuktikan bahwa GCG berpengaruh positif terhadap nilai perusahaan. Berdasarkan pada hal tersebut diatas maka dapat ditarik hipotesis sebagai berikut:

$\mathrm{H}_{1}$ : $G C G$ berpengaruh signifikan terhadap nilai perusahaan perbankan yang terdaftar di BEI.

\section{Pengaruh Profitabilitas Terhadap Nilai Perusahaan}

Semakin tinggi profitabilitas, maka laba yang tersedia untuk dibagikan kepada pemegang saham juga menjadi lebih besar. Hal ini akan memberikan sinyal ke publik bahwa perusahaan relatif tidak mudah mengalami kebangkrutan dan bentuk lain dari financial distress sehingga nilai perusahaan akan meningkat. Dalam penelitian ini, profitabilitas diukur dengan rasio Return on Asset (ROA) dan Return on Equity (ROE). Peningkatan ROA dan ROE menunjukkan prospek perusahaan yang semakin baik, yang akan dianggap sebagai sinyal positif oleh investor yang selanjutnya mempermudah 
manajemen perusahaan untuk menarik modal dalam bentuk saham. Apabila terjadi kenaikkan permintaan saham, maka akan menaikkan harga saham tersebut di pasar modal (dengan asumsi ceteris paribus). Penelitian Chen \& Chen (2011) serta Hendrayana dan Yasa (2015) membuktikan bahwa profitabilitas (ROA) berpengaruh positif terhadap nilai perusahaan. Penelitian yang dilakukan oleh Hermuningsih (2013) menemukan bahwa ROA dan ROE berpengaruh positif terhadap nilai perusahaan. Sedangkan hasil penelitian Fahrizal (2013) menunjukkan bahwa profitabilitas (ROE) berpengaruh negatif terhadap nilai perusahaan. Berdasarkan pada hal tersebut diatas maka dapat ditarik hipotesis sebagai berikut:

$\mathrm{H}_{2}$ : Return on Asset (ROA) berpengaruh signifikan terhadap nilai perusahaan perbankan yang terdaftar di BEI.

$\mathrm{H}_{3}$ : Return on Equity (ROE) berpengaruh signifikan terhadap nilai perusahaan perbankan yang terdaftar di BEI.

\section{Pengaruh GCG Terhadap Profitabilitas}

Menurut FCGI dalam situsnya www.fcgi.or.id, penerapan GCG akan memberikan beberapa keuntungan seperti lebih mudah dalam mendapatkan modal, biaya modal yang lebih rendah sehingga dapat meningkatkan efisiensi dan berpengaruh baik terhadap kinerja keuangan. Pengaruh GCG terhadap profitabilitas dibuktikan dalam penelitian Joh (2003) yang mengungkapkan bahwa lemahnya penerapan GCG berpengaruh terhadap rendahnya profitabilitas perusahaan. Hasil penelitian ini didukung oleh penelitian yang dilakukan oleh Tjondro dan Wilopo (2011) menunjukkan bahwa penerapan GCG yang baik berpengaruh positif terhadap ROA maupun ROE. Sedangkan Bauer, Guenster dan Otten (2004) serta Zamani dan Moeljadi (2012) mengungkapkan bahwa penerapan GCG berpengaruh negatif terhadap ROE. Berdasarkan pada hal tersebut diatas maka dapat ditarik hipotesis sebagai berikut:

$\mathrm{H}_{4}$ : GCG berpengaruh signifikan terhadap Return on Asset (ROA) perusahaan perbankan yang terdaftar di BEI.

$\mathrm{H}_{5}$ : $G C G$ berpengaruh signifikan terhadap Return on Equity (ROE) perusahaan perbankan yang terdaftar di BEI.

\section{Pengaruh GCG Terhadap Nilai Perusahaan Melalui Profitabilitas}

Berbagai penelitian telah membuktikan pengaruh GCG terhadap Profitabilitas dan juga pengaruh profitabilitas terhadap nilai perusahaan. FCGI juga mengungkapkan bahwa penerapanya GCG tidak hanya berimbas pada kinerja perusahaan yang lebih baik tetapi juga memberikan pengaruh baik terhadap nilai perusahaan. Sesuai dengan Cadbury Committee of United Kingdom (www.fcgi.or.id) bahwa tujuan dari corporate governance adalah untuk menciptakan nilai tambah bagi stakeholders (termasuk didalamnya pemegang saham). Beberapa hasil penelitian yang mengungkapkan pengaruh GCG terhadap profitabilitas (ROA dan ROE) ditambah dengan penelitianpenelitian yang menunjukkan pengaruh profitabilitas (ROA dan ROE) terhadap nilai perusahaan, maka dapat ditarik hipotesi sebagai berikut:

$\mathrm{H}_{6}$ : $G C G$ berpengaruh signifikan terhadap nilai perusahaan melalui ROA pada perusahaan perbankan yang terdaftar di BEI.

H7: $G C G$ berpengaruh signifikan terhadap nilai perusahaan melalui ROE pada perusahaan perbankan yang terdaftar di BEI. 


\section{METODE PENELITIAN}

Penelitian ini menggunakan pendekatan kuantitatif yang melakukan pengujian terhadap hubungan kausal dari variabel - variabel penelitian yang terukur. Penelitian ini menguji pengaruh GCG terhadap nilai perusahaan dan profitabilitas serta memposisikan variabel profitabilitas sebagai variabel intervening.

\section{Populasi dan Sampel}

Populasi dalam penelitian ini adalah semua perusahaan yang tercatat di subsektor bank di Bursa Efek Indonesia (BEI) selama kurun waktu 2013 - 2015. Data dalam penelitian ini merupakan data panel. Sampel dalam penelitian ini dipilih dengan menggunakan teknik purposive sampling dengan tujuan untuk mendapatkan sampel yang sesuai dengan tujuan penelitian. Tercatat 39 bank yang merupakan anggota populasi, terdapat 4 bank yang baru terdaftar di BEI pada tahun 2014. Dari 35 sampel yang tersisa ada 1 bank yang tidak mempublikasikan nilai komposit GCG secara lengkap selama periode penelitian; dan tidak terdapat anggota populasi yang melakukan stock split ataupun corporate action lainnya yang secara langsung mengakibatkan perubahan harga saham. Sehingga akhirnya didapat 34 perusahaan yang memenuhi kriteria sampel selama periode pengamatan dengan jumlah observasi sebanyak $102(\mathrm{~N}=$ 34 perusahaan $\times 3$ tahun).

\section{Jenis dan Sumber Data}

Jenis data yang digunakan dalam penelitian ini adalah data sekunder, berupa laporan keuangan dan laporan self assessment GCG yang dipublikasikan oleh pihak bank, serta data harga saham. Data yang diperlukan dalam penelitian diperoleh dengan melakukan observasi dan dokumentasi terhadap data yang diperoleh dari situs-situs Bank yang menjadi sampel penelitian dan situs BEI.

\section{Definisi Operasional Variabel}

Variabel dalam penelitian diklasifikasikan menjadi tiga jenis variabel yaitu variabel dependen, variabel independen dan variabel intervening. Variabel dependen (endogen) adalah nilai perusahaan (Y), variabel independen (eksogen) adalah Good Corporate Governance (X), dan variabel intervening adalah Profitabilitas yang terdiri dari ROA dan ROE. Berikut ini adalah definisi operasional dari variabel-variabel tersebut:

a) Nilai perusahaan diukur dengan Price to Book Value (PBV) yang merupakan perbandingan antara harga saham dengan nilai buku per saham.

$$
\mathrm{PBV}=\frac{\text { Price per share }}{\text { Book Value per share }}
$$

b) Good Corporate Governance (GCG) diukur dengan nilai komposit self assessment GCG (1 sampai dengan 5). Sesuai dengan Peraturan Bank Indonesia, semakin kecil nilai komposit berarti penerapan GCG semakin baik. Dimana semakin kecil nilai komposit berarti penerapan GCG semakin baik. Sehingga dalam penelitian ini digunakan nilai GCG reverse yang diperoleh dengan cara berikut ini: 


$$
\text { GCG reverse }=5 \text { - nilai komposit GCG }
$$

c) Return on Asset (ROA) adalah perbandingan laba sebelum pajak dengan rata-rata total aset.

$$
\mathrm{ROA}=\frac{\text { Laba sebelum pajak }}{\text { Rata-rata total Aset }} \times 100 \%
$$

d) Return on Equity (ROE) adalah perbandingan laba setelah pajak dengan rata-rata modal inti.

$$
\mathrm{ROE}=\frac{\text { Laba setelah pajak }}{\text { Rata-rata modal inti }} \times 100 \%
$$

\section{Alat Analisis Data}

Suatu variabel disebut mediator atau intervening jika variabel tersebut ikut mempengaruhi hubungan antara variabel prediktor (independen) dan variabel kriterion (dependen). Untuk mengetahui pengaruh variabel independen (Good Corporate Governance) terhadap variabel dependen (nilai perusahaan) melalui variabel intervening (profitabilitas) digunakan metode analisis jalur (path analysis). Analisis jalur adalah penggunaan analisis regresi untuk menaksir hubungan kausalitas antar variabel yang ditetapkan berdasarkan teori. Hubungan langsung terjadi jika satu atau lebih variabel (variabel independen) mempengaruhi variabel dependen tanpa ada variabel lain yang memediasi (intervening) hubungan variabel tadi. Hubungan tidak langsung adalah jika ada variabel lain yang memediasi hubungan kedua variabel independen dan dependen (Ghozali, 2012).

Agar model regresi menjadi estimator linier yang tidak bias (Best Linier Unbias Estimator/BLUE) maka dilakukan uji normalitas, multikolinieritas, autokorelasi dan heteroskedastisitas pada model regresi. Untuk menguji hipotesis penelitian digunakan uji signifikansi parsial (uji - t) dan uji sobel.

\section{Model Empiris}

$$
\begin{aligned}
& \mathrm{PBV}=\alpha+\beta_{1} \mathrm{GCG}+\beta_{2} \mathrm{ROA}+\beta_{3} \mathrm{ROE}+\mathrm{e}_{1} \\
& \mathrm{ROA}=\alpha+\beta_{1} \mathrm{GCG}+\mathrm{e}_{2} \quad \ldots \ldots \ldots \ldots \ldots \ldots \ldots \ldots \ldots \ldots \\
& \mathrm{ROE}=\alpha+\beta_{1} \mathrm{GCG}+\mathrm{e}_{3} \quad \ldots \ldots \ldots \ldots \ldots \ldots \ldots
\end{aligned}
$$




\section{Gambar 1. Diagram Jalur}

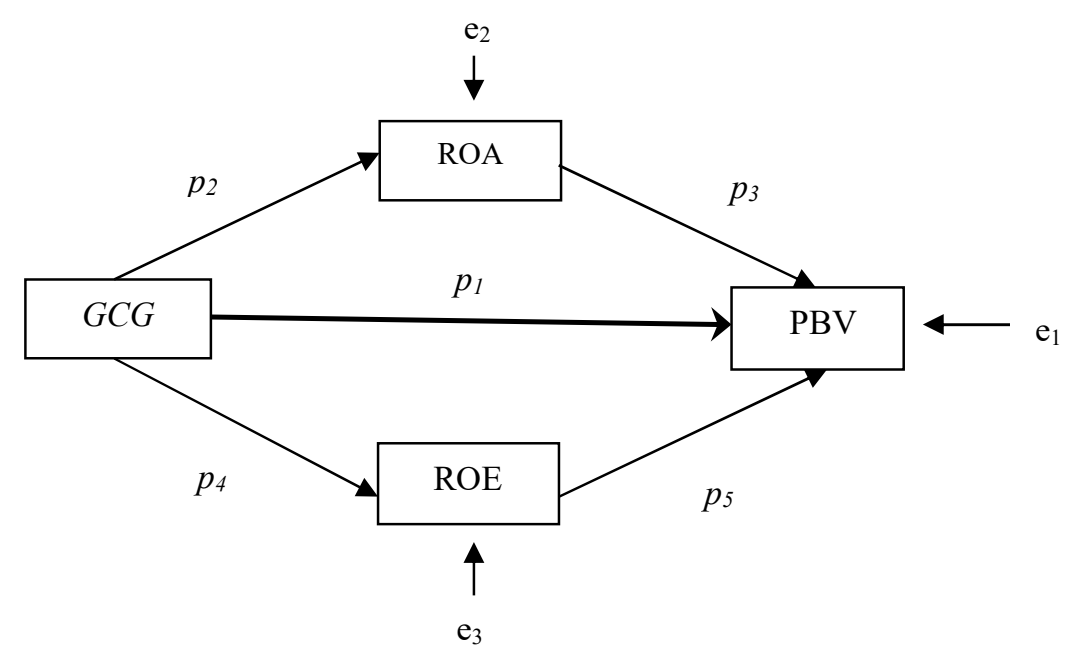

Keterangan gambar:

$$
\begin{aligned}
& p_{1 ;} p_{3 ;} p_{5}=\text { unstandardized coefficient (koefisien jalur) untuk menguji } \\
& \text { pengaruh GCG, ROA dan ROE terhadap PBV } \\
& p_{2} \quad \square \square \text { unstandardized coefficient (koefisien jalur) untuk menguji } \\
& \text { pengaruh GCG terhadap ROA } \\
& p_{4}=\text { unstandardized coefficient (koefisien jalur) untuk menguji } \\
& \text { pengaruh GCG terhadap ROA } \\
& \mathrm{e}_{1} ; \mathrm{e}_{2} ; \mathrm{e}_{3} \quad \square \square \text { error }
\end{aligned}
$$

\section{HASIL DAN PEMBAHASAN}

Demi memenuhi ketentuan dalam uji asumsi klasik maka semua variabel dalam penelitian ini ditransformasikan ke dalam bentuk akar kuadrat (SQRT). Mengingat

\begin{tabular}{|c|c|c|c|c|c|c|}
\hline & \multirow{2}{*}{ Model } & \multicolumn{2}{|c|}{ Unstandardized Coefficients } & \multirow{2}{*}{$\begin{array}{c}\begin{array}{c}\text { Standardized } \\
\text { Coefficients }\end{array} \\
\text { Beta }\end{array}$} & \multirow{2}{*}{$\mathbf{t}$} & \multirow{2}{*}{ Sig. } \\
\hline & & B & Std. Error & & & \\
\hline \multirow[t]{4}{*}{1} & (Constant) & -.205 & .533 & & -.384 & .702 \\
\hline & SQRT GCG & .637 & .310 & .190 & 2.060 & .042 \\
\hline & SQRT ROA & .606 & .132 & .663 & 4.594 & .000 \\
\hline & SQRT ROE & -.125 & .052 & -.345 & -2.407 & .018 \\
\hline
\end{tabular}
bahwa bilangan negatif tidak dapat ditransformasikan ke dalam bentuk SQRT, maka beberapa data yang negatif tidak dapat disertakan sebagai sampel observasi. Sehingga diperoleh total observasi sejumlah $94(\mathrm{~N}=94)$. Selanjutnya data penelitian dianalisis dengan menggunakan analisis regresi. Berikut ini adalah hasil regresi linier berganda dari persamaan yang pertama:

Tabel 1. Hasil Regresi Persamaan Pertama

a. Dependent Variable: SQRT_PBV

Sumber: output SPSS 


\section{Pengaruh GCG terhadap Nilai Perusahaan}

Berdasarkan hasil regresi yang tertera pada tabel 1 diperoleh t-hitung $=2,060$ dan nilai signifikansi sebesar 0,042 (lebih kecil dari 0,05). Hal ini membuktikan bahwa Good Corporate Governance (GCG) berpengaruh positif terhadap nilai perusahaan yang diproksikan dengan Price to Book Value (PBV). Hasil penelitian ini mengindikasikan pengungkapan GCG dianggap sebagai suatu informasi yang penting oleh investor. Hasil penelitian ini konsisten dengan hasil penelitian Bauer, Guenster dan Otten (2004), Retno dan Priantinah (2012), Hendrayana dan Yasa (2015) serta Tempone (2016). Ini berarti hipotesis pertama $\left(\mathrm{H}_{1}\right)$ diterima.

\section{Pengaruh Profitabilitas terhadap Nilai Perusahaan}

Hasil regresi (tabel 1) membuktikan bahwa ROA berpengaruh positif dan signifikan terhadap nilai perusahaan (PBV), yang berarti bahwa hipotesis kedua (H2) diterima. Hal ini ditunjukkan oleh koefisien beta yang positif sebesar 0,606 dan nilai signifikansi 0,000 yang mengindikasikan bahwa peningkatan ROA menunjukkan prospek perusahaan yang semakin baik, yang akan dianggap sebagai sinyal positif oleh investor. Hasil penelitian ini sesuai dengan penelitian Chen \& Chen (2011) serta Hendrayana dan Yasa (2015).

Berdasarkan hasil regresi yang disajikan pada tabel 1 terlihat bahwa ROE berpengaruh negatif dan signifikan terhadap nilai perusahaan (PBV), yang ditunjukkan dengan koefisien beta negatif dengan nilai $\mathrm{t}=-0,125$ dan nilai signifikansi 0,018 . Hasil penelitian ini menunjukkan pengaruh yang kuat dari ROE terhadap nilai perusahaan yang mengindikasikan bahwa peningkatan nilai ROE direspon secara negatif oleh investor. Hal ini sesuai dengan hasil penelitian Fahrizal (2013). Ini berarti bahwa hipotesis ketiga $\left(\mathrm{H}_{3}\right)$ diterima.

\section{Pengaruh GCG terhadap Profitabilitas}

Hasil uji statistik yang menunjukkan pengaruh GCG terhadap ROA dapat dilihat dari tabel berikut ini:

Tabel 2. Hasil Regresi Persamaan Kedua

\begin{tabular}{|c|c|c|c|c|c|c|}
\hline \multicolumn{7}{|c|}{ Coefficients $^{\mathrm{a}}$} \\
\hline & \multirow[t]{2}{*}{ Model } & \multicolumn{2}{|c|}{ Unstandardized Coefficients } & \multirow{2}{*}{$\begin{array}{c}\begin{array}{c}\text { Standardized } \\
\text { Coefficients }\end{array} \\
\text { Beta }\end{array}$} & \multirow[t]{2}{*}{$\mathbf{t}$} & \multirow[t]{2}{*}{ Sig. } \\
\hline & & B & Std. Error & & & \\
\hline \multirow[t]{2}{*}{1} & (Constant) & -.284 & .656 & & -.433 & .666 \\
\hline & SQRT_GCG & .798 & .373 & .218 & 2.141 & .035 \\
\hline
\end{tabular}

Sumber: output SPSS

Berdasarkan tabel 2 diperoleh nilai koefisien beta sebesar 0,798 dengan t-hitung $=2,141$ dan nilai signifikansi 0,035. Hasil ini menunjukkan bahwa GCG berpengaruh positif dan signifikan terhadap ROA. Sehingga hasil penelitian ini mengungkapkan bahwa semakin baik penerapan GCG maka semakin tinggi ROA yang dihasilkan perusahaan. Hal ini mengindikasikan bahwa semakin baik penerapan GCG maka pengelolaan aset akan semakin efisien, sehingga manajemen dapat menghasilkan tingkat pengembalian (return) yang tingi. Hasil penelitian ini sesuai dengan hasil penelitian yang dilakukan oleh Joh (2003) serta Tjondro dan Wilopo (2011). Ini berarti bahwa hipotesis keempat $\left(\mathrm{H}_{4}\right)$ dalam penelitian ini diterima. 
Hasil uji statistik yang menunjukkan pengaruh GCG terhadap ROE disajikan pada tabel 3 .

Tabel 3. Hasil Regresi Persamaan Ketiga

\begin{tabular}{|c|c|c|c|c|c|c|}
\hline \multicolumn{7}{|c|}{ Coefficients $^{\mathrm{a}}$} \\
\hline & \multirow{2}{*}{ Model } & \multicolumn{2}{|c|}{ Unstandardized Coefficients } & $\begin{array}{c}\text { Standardized } \\
\text { Coefficients }\end{array}$ & \multirow{2}{*}{$\mathbf{t}$} & \multirow{2}{*}{ Sig. } \\
\hline & & B & Std. Error & Beta & & \\
\hline \multirow[t]{2}{*}{1} & \begin{tabular}{|l|l} 
(Constant) \\
\end{tabular} & .009 & 1.664 & & .005 & .996 \\
\hline & SQRT_GCG & 1.760 & .945 & .191 & 1.862 & .066 \\
\hline
\end{tabular}

Sumber: output SPSS

Persamaan regresi yang ketiga ditujukan untuk menguji pengaruh GCG terhadap ROE. Diperoleh nilai koefisien beta sebesar 1,760 dengan t-hitung $=1.862$ dan nilai signifikansi 0,066. Karena nilai signifikansi lebih besar dari nilai $\alpha(0,05)$, berarti pengaruh GCG terhadap ROE tidaklah signifikan. Sehingga dapat disimpulkan bahwa GCG tidak berpengaruh terhadap ROE. Hal ini mengindikasikan bahwa penerapan GCG yang dilakukan oleh perusahaan belum mengarah pada penciptaan tingkat pengembalian atas ekuitas yang tinggi (seperti yang diharapkan oleh para pemegang saham). Ini berarti bahwa hipotesis kelima $\left(\mathrm{H}_{5}\right)$ ditolak.

\section{Pengaruh GCG terhadap Nilai Perusahaan melalui Profitabilitas}

Berikut ini adalah gambar yang menunjukkan hubungan antar variabel bebas (exsogen variable), variabel terikat (endogen variable) dan variabel intervening dalam penelitian ini, yang juga dilengkapi dengan koefisien jalur. Nilai dari koefisien jalur $p_{1}$ pada gambar 2 menunjukkan besarnya pengaruh langsung variabel GCG terhadap PBV, dimana pengaruhnya adalah signifikan. Dari gambar 2 juga terlihat bahwa variabel GCG berpengaruh secara signifikan terhadap ROA namun tidak berpengaruh terhadap ROE, yang ditunjukkan dengan koefisien jalur $p_{2}$ dan $p_{4}$. Sedangkan pengaruh ROA dan ROE terhadap PBV ditunjukkan dengan koefisien jalur $p_{3}$ dan $p_{5}$. Telah terungkap bahwa variabel profitabilitas, baik ROA maupun ROE berpengaruh secara signifikan terhadap PBV.

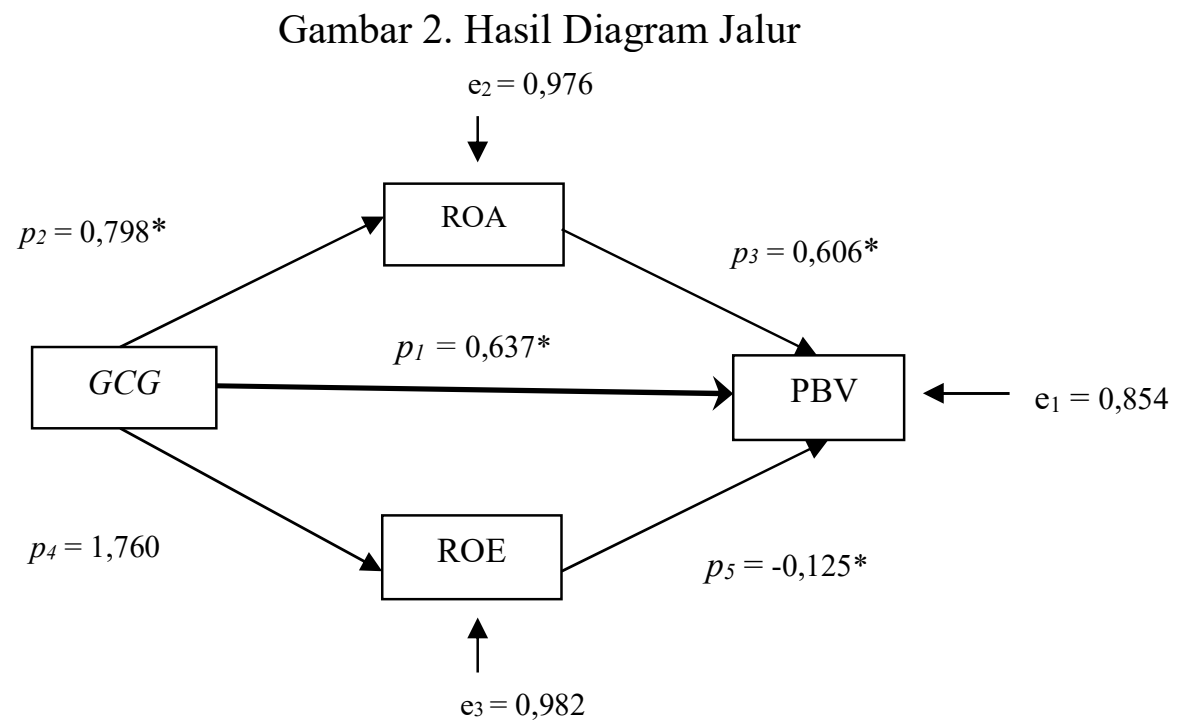

Pengaruh Good Corporate Governance Terhadap Nilai Perusahaan... $\mid 55$ 
Keterangan Gambar 1:

* : berpengaruh signifikan dengan $\alpha=0,05$

Pada tabel 4 tertuang hasil perhitungan pengaruh tidak langsung (koefisien mediasi) dan pengaruh total dari variabel GCG terhadap variabel PBV melalui variabel ROA dan ROE. Uji sobel dilakukan untuk menguji signifikansi pengaruh tidak langsung dari variabel eksogen terhadap variabel endogen. Dalam uji sobel, nilai thitung dari pengaruh tak langsung dibandingkan dengan $t$ tabel.

Tabel 4. Pengaruh Tidak Langsung dan Total

\begin{tabular}{|c|c|c|c|c|c|c|c|}
\hline $\begin{array}{l}\text { Variabel } \\
\text { Eksogen }\end{array}$ & $\begin{array}{c}\text { Variabel } \\
\text { intervening }\end{array}$ & $\begin{array}{l}\text { Variabel } \\
\text { Endogen }\end{array}$ & $\begin{array}{l}\text { Pengaruh } \\
\text { langsung }\end{array}$ & $\begin{array}{l}\text { Pengaruh } \\
\text { tidak } \\
\text { langsung }\end{array}$ & $\begin{array}{l}\text { Total } \\
\text { Effect }\end{array}$ & $\begin{array}{l}\text { Std. error } \\
\text { pengaruh } \\
\text { tak } \\
\text { langsung } \\
\end{array}$ & t-hitung \\
\hline \multirow{2}{*}{ GCG } & $\mathrm{ROA}$ & \multirow{2}{*}{ PBV } & \multirow{2}{*}{$0.637 *$} & 0.484 & 1.121 & 0.254 & 1.902 \\
\hline & ROE & & & -0.220 & 0.417 & 0.157 & -1.399 \\
\hline
\end{tabular}

Keterangan:

$*$ = signifikan pada $\alpha=0,05$

Dari hasil uji sobel diperoleh nilai t-hitung pengaruh tidak langsung GCG terhadap PBV melalui ROA lebih kecil dari t-tabel $(1,98)$ yang berarti bahwa variabel ROA tidak dapat memediasi pengaruh dari GCG terhadap PBV. Sehingga dapat dikatakan bahwa tidak terdapat pengaruh tidak langsung antara penerapan GCG terhadap nilai perusahaan. Dengan demikian maka hipotesis keenam $\left(\mathrm{H}_{6}\right)$ ditolak.

Hasil uji pengaruh tidak langsung GCG terhadap PBV melalui ROE juga dapat dilihat dari tabel 4.13 di atas. Nilai t-hitung yang diperoleh adalah $-1,399$, dimana nilai ini lebih kecil nilai t-tabel $(1,98)$. Hasil ini menunjukkan bahwa ROE tidak dapat memediasi pengaruh dari GCG terhadap PBV. Ini berarti hipotesis ketujuh $\left(\mathrm{H}_{7}\right)$ ditolak. Sehingga dapat disimpulkan bahwa profitabilitas baik ROA maupun ROE, tidak dapat memediasi pengaruh GCG terhadap PBV. Hal ini disebabkan karena variabel GCG sendiri memiliki pengaruh langsung terhadap nilai perusahaan yang diproksikan dengan PBV.

\section{KESIMPULAN DAN SARAN}

\section{Kesimpulan}

Berdasarkan uraian dalam pembahasan maka dapat disimpulkan bahwa:

1) GCG berpengaruh positif terhadap nilai perusahaan perbankan yang terdaftar di BEI tahun $2013-2015$.

2) Profitabilitas berpengaruh secara signifikan terhadap nilai perusahaan, dimana ROA berpengaruh positif terhadap nilai perusahaan perbankan sedangkan ROE berpengaruh negatif terhadap nilai perusahaan perbankan yang terdaftar di BEI tahun $2013-2015$.

3) Penerapan GCG berpengaruh positif terhadap profitabilitas yang diproksikan dengan ROA pada perusahaan perbankan yang terdaftar di BEI tahun $2013-2015$.

4) Penerapan GCG tidak berpengaruh terhadap ROE pada perusahaan perbankan yang terdaftar di BEI tahun 2013 - 2015. 
5) Profitabilitas tidak dapat memediasi pengaruh GCG terhadap nilai perusahaan, sehingga pengaruh tidak langsung GCG terhadap nilai perusahaan melalui profitabilitas tidak dapat dibuktikan.

\section{Saran}

Berdasarkan kesimpulan di atas disarankan beberapa hal sebagai berikut:

1) Bagi pihak manajemen bank agar lebih memperhatikan penerapan prinsip tata kelola yang baik (GCG) bukan hanya sebatas mematuhi aturan saja, karena hasil penelitian ini menunjukkan bahwa semakin baik penerapan GCG akan berdampak pada profitabilitas perusahaan dan nilai perusahaan.

2) Bagi peneliti selanjutnya disarankan untuk melakukan penelitian di sektor yang lainnya yang memiliki populasi yang lebih besar sehingga bisa didapatkan jumlah sampel yang lebih besar tanpa harus menggunakan data panel. Selain itu peneliti selanjutnya diharapkan dapat meneliti lebih lanjut berkenaan dengan penerapan Good Corporate Governance dan pengaruhnya terhadap kinerja perusahaan secara menyeluruh (tidak hanya sebatas profitabilitas).

\section{DAFTAR PUSTAKA}

Atmaja, Lukas Setia. (2008). Teori dan Praktik Manajemen Keuangan. Yogyakarta: Penerbit ANDI.

Brigham, E. F., \& Daves, P. R. (2004). Intermediate Financial Management (International Student - 8th ed.). USA: Thomson South-Western.

Budiartini, D. A., Rudy, D. G., \& Purwanti, N. P. (2012). Pelanggaran Prinsip-Prinsip Good Corporate Governance Di Pasar Modal (Studi Kasus Pada PT Bank Lippo Tbk). Kertha Wicara, Volume 1 nomor 2.

Chen, L. J., \& Chen, S. Y. (2011). The Influence of Profitability on Firm Value with Capital Structure as The Mediator and Firm Size and Industry as Moderators. Investment Management and Financial Innovations, Volume 8, Issue 3, pg. 121129.

Fahrizal, Helmy. (2013). Pengaruh Return On Asset (ROA), Return On Equity (ROE) dan Invesment Opportunity Set (IOS) Terhadap Nilai Perusahaan. Skripsi, Fakultas Ekonomi dan Bisnis Universitas Islam Negeri Syarif Hidayatullah, Jakarta.

Ghozali, Imam. (2012). Aplikasi Analisis Multivariate Dengan Program IBM SPSS 20 (edisi 6). Semarang: Badan Penerbit Universitas Diponegoro.

Hendrayana, P. W., \& Yasa, G. W. (2015). Pengaruh Komponen RGEC Pada Perubahan Harga Saham Perusahaan Perbankan di Bursa Efek Indonesia. EJurnal Akuntansi Universitas Udayana, 11.1, halaman 74 - 89.

Hermuningsih, Sri. (2013). Pengaruh Profitabilitas, Growth, Opportunity, Sruktur Modal terhadap Nilai Perusahaan Pada Perusahaan Publik di Indonesia. Buletin Ekonomi Moneter dan Perbankan, Volume 16 (Nomor 2), halaman 127-148.

Joh, S. W. (2003). Corporate governance and firm profitability: evidence from Korea before the economic crisis. Journal of Financial Economics 68 , halaman 287322.

Kemalasari, E. (2009). Pengaruh Penerapan Good Corporate Governance Terhadap Kinerja Perusahaan Perbankan Yang Terdaftar di Bursa Efek Indonesia. Tesis, 
Sekolah Pascasarjana Universitas Sumatera Utara, Program Studi Akuntansi, Medan.

Retno, R. D., \& Priantinah, D. (2012). Pengaruh Good Corporate Governance dan Pengungkapan Corporate Social Responsibility Terhadap Nilai Perusahaan (Studi Empiris Pada Perusahaan Yang Terdaftar di Bursa Efek Indonesia Periode 2007-2010). Jurnal Nominal, volume 1, nomor 1, halaman 84-103.

Sartono, Agus. (2001). Manajemen Keuangan: Teori dan Aplikasi (Edisi Keempat, Cetakan Pertama ed.). Yogyakarta: BPFE.

Tempone, S. O. (2016). Pengaruh Tingkat Kesehatan Bank Dengan Metode RGEC Terhadap Return Saham Pada Sektor Perbankan Yang Terdaftar di BEI Tahun 2012-2014. Skripsi, Fakultas Ekonomi dan Bisnis Universitas Airlangga, Surabaya.

Tjondro, D., \& Wilopo, R. (2011). Pengaruh Good Corporate Governance Terhadap Profitabilitas dan Kinerja Saham Perusahaan Perbankan Yang Tercatat di Bursa Efek Indonesia. Journal of Business and Banking, volume 1, no. 1, pg. 1-14.

Zamani, M. I., \& Moeljadi. (2012). Kinerja Keuangan Sebelum dan Sesudah Penerapan Good Corporate Governance Pada PT Bank Negara Indonesia Tbk. Dengan Rasio ROA, ROE dan CAR. Jurnal Mahasiswa FEB Universitas Brawijaya, Volume 1 nomor 1.

Peraturan:

KNKG. (2012). Prinsip Dasar dan Pedoman Pelaksanaan Good Corporate Governance Perbankan Indonesia (Draft Perbaikan 9 Januari 2013).

Peraturan Bank Indonesia No. 8/14/PBI/2006

Peraturan Bank Indonesia nomor 13/1/PBI/2011

Surat Edaran Bank Indonesia nomor 15/15/ DPNP, diterbitkan tanggal 29 April 2013.

Website:

www.fcgi.or.id

www.idx.co.id 